\title{
PENGEMBANGAN SISTEM E-PAYMENT UNTUK MEMBANTU PENGAMBILAN KEPUTUSAN STUDI KASUS: UNIVERSITAS BANTEN JAYA
}

\author{
Drs. H. Suba'i, MM ${ }^{1}$ \\ Irma Yunita Ruhiawati ${ }^{2}$ \\ Dosen Fakultas Ilmu Komputer Universitas Banten Jaya \\ Jl. Ciwaru II No. 73, Kota Serang - Banten \\ Email: Subai.srg@yahoo.co.id ${ }^{1}$, iyr.yoenita@gmail.com ${ }^{2}$
}

\begin{abstract}
ABSTRAK
Data keuangan mahasiswa merupakan unsur penting pada suatu sistem manajemen pendidikan yang merupakan salah satu bagian administrasi. untuk memperoleh pendidikan tinggi, dibutuhkan biaya pendidikan untuk menunjang fasilitas pendidikan. Akan tetapi pembayaran biaya pendidikan yang dilakukan secara manual akan membutuhkan banyak tenaga, waktu, pikiran serta keamanan data yang belum terjamin keamanannya. Dengan seiringnya waktu, teknologi berkembang semakin pesat dan saat ini hadir sistem pembayaran elektronik atau epayment melayani dan mengolah transaksi setoran kuliah secara online serta menyediakan informasi dalam setiap transaksi dengan cepat dan akurat sehingga banyak digunakan di berbagai bidang. Selain itu pembayaran transaksi dengan sistem online merupakan kerjasama yang saling menguntungkan dan dapat diterima dalam masyarakat karena dengan sistem ini dapat memperkecil resiko terjadinya tindak kejahatan, kehilangan data dan mempermudah proses setoran.Hal ini tentu sangat membantu bagian keuangan di Universitas Banten Jaya. Sistem ini dirancang dengan metode pengembangan sistem menggunakan waterfall dengan unified modeling language (UML) sebagai media pemodelannya. Pemrograman berbasis web dipilih dansebagai bahasa pemrograman dalam pengembangan sistem ini dilengkapi dengan dashboard dan smart filtering untuk mempermudah pimpinandanbagiankeuangan dalam memperoleh dan memahami informasi. Hasilnya sistem e-payment dapat membantu manajemen di keuangan dalam memantau setiap kelemahan yang ada untuk terus diperbaiki agar menjadi lebih baik.
\end{abstract}

Kata kunci : sistem, informasi, pembayarn elektronik, dashboard.

\begin{abstract}
Student financial data is a essential element in a system of education management. To obtain higher education, needed the cost of education to support education facilities. But payment of the costs of education to be done manually would need much power, time, the mind and security the data is not guaranteed security. In the modern era, technology developing the rapidly and when this present a system of electronic pricing or e-payment serve and process contribution transactions college online and provide information in any transaction quickly and accurate.So many used in various fields beside as the payment transaction with the online system a form of cooperation that is mutually advantageous and acceptable in the community because with this system can minimize the risk of criminal acts, Lost the data and make it easy for subscription of the process This system designed with method of development system using waterfall with the unified modeling language ( $\mathrm{uml}$ ) as a media model Web based programming chosen as programming language in the development of this system furnished with dashboard and smart filtering to ease leader and finance division in obtaining and understand information
\end{abstract}


the results e-payment system can help financial management of in monitoring every the weaknesses that exist to keep repaired so as to get better

Keywords: system, information, e-payment, dashboard.

\section{PENDAHULUAN}

Untuk memperoleh pendidikan tinggi dibutuhkan biaya pendidikan untuk menunjang fasilitas pendidikan. Akan tetapi pembayaran biaya pendidikan yang dilakukan secara manual akan membutuhkan banyak tenaga, waktu, pikiran serta keamanan data yang belum terjamin keamanannya. Dengan seiringnya waktu, teknologi berkembang semakin pesat dan banyak memberikan manfaat juga kemudahan sehingga banyak digunakan di berbagai bidang. Kini pembayaran biaya pendidikan di UNBAJA mulai beralih dari manual ke sistem informasi karena pembayaran secara manual membutuhkan banyak tenaga, waktu, dan pikiran terutama untuk pengolahan data, penyimpanan data, pengaturan sistem yang biasa dilakukan secara manual serta keamanan data yang belum terjamin.

Proses bisnis dan sistem informasi merupakan suatu keharusan yang berperan penting dalam dunia bisnis saat ini. Saat proses bisnis dan sistem informasi sudah begitu baik, maka dibutuhkan sistem pembayaran dari tiap transaksi bisnis yang berlangsung. Jika menggunakan transaksi manual maka hal tersebut sangat kurang efisien untuk membantu menyelesaikan proses bisnis yang sedang berlangsung, sistem pembayaran ini merupakan suatu terobosan yang baik ditengah perkembangan teknologi informasi yang makin hari makin berkembang dan dapat mendukung setiap sudut kegiatan baik kegiatan di perusahaan, di pemerintahan hingga dalam pembiayaan pendidikan tinggi. Sistem pembayaran ini akan memanfaatkan teknologi informasi yang disebut sistem pembayaran online atau e-payment yang mana nantinya mahasiswa yang ingin menyelesaikan biaya perkuliahan cukup mentransfer melalui bank yang sudah ditunjuk oleh pihak penyelenggara pendidikan dan jika mahasiswa yang sudah membayar maka akan secara otomatis dapat langsung diverifikasi oleh bagian staff pelayanan di bagian keuangan pihak penyelenggara pendidikan. Sehingga hal ini akan mempermudah proses pengolahan data administrasi keuangan mahasiswa itu sendiri didalam menjalani proses pendidikan, dimana pada bagian administrasi keuangan ini akan menjadi tolak ukur didalam menentukan proses selanjutnya pada perkuliahan mahasiswa.

Maka berdasarkan hal-hal yang telah dipaparkan diatas, di dalam sistem administrasi keuangan berbasis e-payment sangat penting dan untuk dapat membantu didalam mendukung suatu keputusan didalam menyelesaikan suatu masalah. Oleh karena itu, peneliti tertarik untuk mengangkat masalah ini kedalam penelitian yang berjudul Membangun Sistem E-Payment Mahasiswa Untuk Membantu Pengambilan Keputusan (Studi Kasus Universitas Banten Jaya). 


\section{PERMASALAHAN}

Permasalahan yang ada pada sistem pembayaran akademik mahasiswa di Universitas Banten Jaya merupakan tanggung jawab bagi pihak penyelenggara pendidikan didalam melayani peserta didiknya dengan baik dimanapihak penyelenggara pendidikan yang memiliki fakultas ilmu komputer untuk membangun generasi masyarakat ke era berteknologi dimana telah mengadopsi peran teknologi komputer untuk menyelesaikan setiap permasalahan di setiap bidang pekerjaan sehingga jika sistem pelayanan yang ada masih kuno, hal ini akan memberikan dampak yang kurang baik dan tidak seirama dengan pendidikan tinggi yang ada. Hadirnya teknologi informasi komputer mendorong setiap sumber daya yang ada untuk dapat terbiasa di dalam melaksanakan setiap pekerjaan dengan sempurna sehingga dapat berjalan dengan efektif dan juga efisien.Untuk dapat memberikan suatu pelayanan yang baik pada peserta didik dan juga mengangkat nilai suatu penyelenggara pendidikan yang memiliki fakultas ilmu komputer hal ini sangat dibutuhkan suatu sistem yang tidak cukup hanya sekedar terkomputerisasi tetapi juga memiliki sistem yang dapat berperan sebagai operator untuk membantu pelayanan pada sistem pembayaran mahasiswa tersebut menjadi lebih cepat, mudah terindentifikasi dan terverifikasi untuk dapat membuka pintu pada sistem selanjutnya di form validasi pembayaran mahasiswa.

Berdasarkan latar belakang tersebut, dapat dirumuskan identifikasi permasalahan yang menjadi dasar dari penelitian ini, yaitu: "Perlu dikembangkan sistem administrasi pembayaran perkuliahan yang lebih mudah dan juga lebih efektif untuk untuk dapat meningkatkan kualitas pelayanan kepada mahasiswa juga untuk membantu pihak keuangan didalam memantau seluruh transaksi menjadi informasi-informasi yang mudah untuk diperoleh sehingga hal ini memberikan dampak yang cukup baik di dalam proses menyelenggarakan pendidikan yang selaras dengan perkembangan teknologi dan informasi.

Adapun masalah yang terjadi dapat dirangkum oleh peneliti adalah :

1. Pendataan yang manual membutuhkan waktu yang lebih lama menyebabkan antrian kepada mahasiswa yang ingin segera menyelesaikan administrasi keuangan karena berkaitan dengan proses perkuliahan di bagian akademik atau hanya sekedar mengecek jumlah administrasi pembayaran kuliah yang sudah masuk.

2. Terdapat penggalian informasi masih yang dirasa cukup lemah dan banyak memakan waktu serta energi sebagai contoh pihak keuangan harus mengumpulkan data-data pembayaran sudah ada untuk dapat menghasilkan suatu informasi data tunggakan mahasiswa satu persatu dan juga untuk dapat menghasilkan data pembayaran yang sudah lunas selain itu informasi mengenai jumlah pembayaran yang sudah masuk dan sebagainya.

3. Sistem administrasi yang ada tidak memiliki kekuatan yang dapat menghasilkan informasi statistik pembayaran secara cepat dan akurat yang berkaitan data keuangan mahasiswa dari bulan ke bulan dan dari tahun ketahun karena untuk menghasilkan hal ini memerlukan waktu dan ketelitian yang cukup memakan waktu serta energi ditambah lagi banyaknya tugas yang harus dikerjakan.

4. Pihak administrasi keuangan kerap kesulitan setiap akhir bulan untuk membuat laporan validasi administrasi keuangan mahasiswa pada setiap akhir bulan.

5. Integrasi data merupakan fungsi pokok yang teramat penting didalam menjaga keutuhan data pembayaran kuliah mahasiswa serta mengakomodir kebutuhan data sehingga menghasilkan informasi yang cepat dan kurat, hal ini belum dapat 
dilakukan mengingat sistem yang dilakukan saat ini masih dilakukan secara terpisah anatar pihak bank dan juga keuangan terlebih pada sistem akademik yang sudah ada.

\section{LANDASAN TEORI DAN LITERATURE REVIEW}

\section{Definisi Pembayaran Elektronik (e-payment)}

Pembayaran adalah proses pertukaran mata uang atau nilai moneter untuk barang, jasa, atau informasi (Chan Kah Sing, 2004:108). Menurut Hasibuan (2001:117) dalam buku Manajemen Sumber Daya Manusia mengemukakan bahwa pembayaran adalah berpindahnya hak kepemilikan atas sejumlah uang atau dan dari pembayar kepada penerimanya, baik langsung ataupun melalui jasa-jasa perbankan.

Pembayaran elektronik mengacu kepada suat transaksi sehingga bisa disebut juga transaksi elektronik, transaksi elektronik menurut Erikson Damanik (2012:7) dikutip dari Ghifary (2010) dalam penelitiannya yang berjudul Perancangan Sistem Informasi Pembayaran Online Menggunakan Payment Gatewayadalah transaksi yang melibatkan pertukaran nilai keuangan. Ada nilai uang yang berkurang dan bertambah pada pihak tertentu.Dengan demikian, transaksi seperti yang terjadi pada data sharing yang dilakukan di Napster, meskipun juga terdapat pertukaran di dalamnya, tidak termasuk hitungan.Pertukaran nilai keuangan berarti ada kegiatan pembayaran di dalamnya. Ada banyak cara pembayaran yang mendukung transaksi elektronik dan ecommerce, di antaranya :.

a. Kartu pembayaran elektronik (baik debit maupun kredit)

b. E-wallets/e-purses (dompet elektronik)

c. Smart cards

d. Pembayaran nirkabel (wireless payments)

e. Stored-value card payments

f. Loyalty cards

g. Person-to-person payment methods.

h. Pembayaran elektronik pada kios - kios khusus.

Pembayaran pada transaksi elektronik pada dasarnya sama dengan pembayaran kartu kredit, hanya saja tanpa kehadiran fisik kartunya. Seperti yang telah disinggung sebelumya, sebagai pengganti kehadiran kartu, ada informasi berkaitan dengan kartu kredit yang dipertukarkan.

Anshori, Mochammad Hafiz (2014:1) dalam penelitiannya menjelaskan sistem pembayaran elektronik memberikan dua keunggulan, yaitu faktor otentifikasi dan respon cepat.Enkripsi pada kode QR dapat meningkatkan keamanan dalam bertransaksi. 


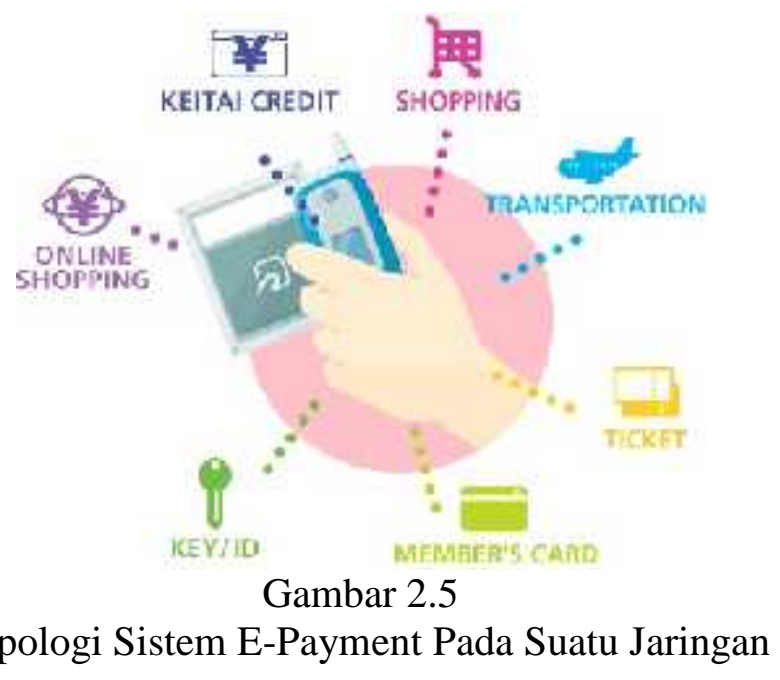

Menururt Anita (2013) dalam Sofyan (2015:10) menjelaskan bahwa yang dimaksud dengan pembayaran elektronis adalah pembayaran yang memanfaatkan teknologi informasi dan komunikasi seperti Integrated Circuit (IC), cryptography dan jaringan komunikasi. Pembayaran elektronis yang kita kenal dan sudah ada di Indonesia saat ini antara lain phone banking, internet banking, kartu kredit dan kartu debit atau ATM. Meskipun teknologi yang digunakan berbeda-beda, seluruh pembayaran elektronis tersebut selalu terkait langsung dengan rekening nasabah bank yang menggunakannya. Dalam hal ini setiap instruksi pembayaran yang dilakukan nasabah, baik melalui phone banking, internet banking, kartu kredit maupun kartu debit atau ATM, selalu melalui proses otorisasi dan akan dibebankan langsung ke dalam rekening nasabah tersebut.

Dari pengertian-pengertian diatas, maka dapat disimpulkan pengertian EPayment adalah suatu sistem pembayaran yang dapat dilakukan oleh beberapa pihak seperti perbankan, pelaku bisnis (vendor ataupun konsumen) dan pelaku sosial yang dilaksanakan secara elektronik melalui suatu jaringan teknologi dan informasi yang canggih.Dengan begitu maka sistem pembayaran elektronik merupakan suatu sistem pembayaran alternatif yang memudahkan konsumen melakukan pembayaran melalui jaringan atau internet.Dalam sistem pembayaran elektronik, semua data pembayaran terdigitalisasi.

\section{Literature Review}

Banyak penelitian yang sebelumnya (literature review) dilakukan mengenai pembahasan tentang pembayaran elektronik atau yang lebih banyak dikenal sebagai epayment yang berbasis online pada dunia pendidikan saat ini.Dalam melakukan pengembangan OJRS+ ini perlu dilakukan studi pustaka untuk dijadikan sebagai bahan acuan untuk memperkuat hasil penelitian dengan cara mengindentifikasikan metose yang pernah dilakukan, mengembangkan penelitian sebelumnya yang memiliki korelasi yang seimbang dengan implementasi sistem e-payment di Universitas Banten Jaya. Beberapa literature review yang didapakan diantaranya adalah sebagai berikut : 
1. Wilko Bolt, David Humphrey, and Roland Uittenbogaard dalam penelitiannya yang berjudul "Transaction Pricing and the Adoption of Electronic Payments: A CrossCountry Comparison". Sebagai keselamatan, efisiensi sistem pembayaran suatu negara adalah perhatian utama dari bank sentral. Karena pembayaran elektronik biasanya lebih murah daripada pembayaran berbasis kertas atau uang tunai, penentuan harga transaksi ini harus mempercepat pergeseran ke elektronik. Tapi seberapa banyak? Norwegia eksplisit dari point-of-sale dimana transaksi tagihan pembayaran cepat bergeser ke pembayaran elektronik, sementara Belanda mengalami pergeseran yang sama tanpa harga. Mengendalikan ketersediaan terminal dan perbedaan antara negara-negara, harga langsung mempercepat pergeseran untuk elektronik sekitar 20 persen. The quid pro quo adalah penghapusan pendapatan mengambang suatu bank..

2. Veronica S. Moertini , Asdi A. Athuri, Hery M. Kemit, Nico Saputro dalam penelitianny yang berjudul "The Development Of Electronic Payment System For Universities In Indonesia: On Resolving Key Success Factors". Untuk mencapai keberhasilan suatu proyek, strategi untuk menghindari dan mengurangi risiko harus dirancang dengan cermat dan dilaksanakan sesuai. Makalah ini menyajikan metode untuk menghindari dan mengurangi risiko seluruh pengembangan sistem informasi, khususnya elektronik sistem pembayaran untuk menangani kuliah di perguruan tinggi di Indonesia. Kebijakan universitas, peraturan dan model sistem yang desain sedemikian rupa untuk menyelesaikan proyek faktor kunci keberhasilan. Dengan menerapkan metode yang diusulkan, sistem telah berhasil dikembangkan dan saat ini dioperasikan. Penelitian ini dilakukan di Universitas Katolik Parahyangan, Bandung, Indonesia..

3. Singh Sumanjeet, University of Delhi, India dalam penelitiannya yang berjudul "Emergence Of Payment Systems In The Age Of Electronic Commerce: The State Of Art". Munculnya e-commerce telah menciptakan kebutuhan keuangan baru yang dalam banyak kasus tidak dapat secara efektif dipenuhi oleh sistem pembayaran tradisional. Menyadari hal ini, pihak hampir semua tertarik mengeksplorasi berbagai jenis sistem pembayaran elektronik dan isu seputar sistem pembayaran elektronik dan mata uang digital. Secara sistem pembayaran elektronik dapat diklasifikasikan ke dalam empat kategori: Sistem Pembayaran Kartu Kredit Online, Sistem Kas Elektronik, Cek Sistem Elektronik dan Sistem Smart Card berbasis Pembayaran Elektronik. Setiap sistem pembayaran memiliki kelebihan dan kekurangan bagi pelanggan dan pedagang. sistem pembayaran ini memiliki jumlah persyaratan: mis keamanan, penerimaan, kenyamanan, biaya, anonimitas, kontrol, dan mampu telusur. Oleh karena itu, bukan berfokus pada spesifikasi teknologi berbagai sistem pembayaran elektronik, peneliti memiliki sistem pembayaran elektronik dibedakan berdasarkan pada apa yang sedang dikirim melalui jaringan; dan menganalisis perbedaan dari masing-masing sistem pembayaran elektronik dengan mengevaluasi kebutuhan mereka, karakteristik dan menilai penerapan masing-masing sistem.

4. "E-Payment System on E-Commerce in India", Oleh Karamjeet Kaur, Ashutosh Pathak dari Journal of Engineering Research and Applications ijeera.com (Karamjeet Kaur, Dr. Ashutosh Pathak, 2013) menerangkan bahwa Sistem epayment adalah Dalam lingkungan e-commerce, electronic payment mengambil bentuk pertukaran uang dalam bentuk elektronik, dan karena itu disebut Pembayaran Elektronik, Sistem E-Payment dianggap sangat aman tidak ada 
ancaman ke nomor kartu kredit pengguna atau kartu pintar lainnya , pembayaran dapat dilakukan tanpa keterlibatan pihak ketiga, membuat pembayaran elektronik setiap saat melalui internet langsung dengan cara mentransfer.

5. "Electronic Payment Systems Development In A Developing Country: The Role Of Institutional Arrangements", Oleh Austin Briggs, Laurence Brooks (2011) dari The Electronic Journal on Information Systems in Developing Countries http://www.ejisdc.org (Austin Briggs, Laurence Brooks, 2011) makalah ini membahas pengaturan kelembagaan dalam pengembangan sistem pembayaran elektronik Nigeria (EPS) menggunakan ekonomi baru institusional (NIE) perspektif Sebuah studi kasus EPS Nigeria dilakukan dengan menggunakan wawancara semi terstruktur untuk mengumpulkan data dari 18 stakeholder berpartisipasi;. metode yang digunakan untuk analisis data adalah tematik. studi ini menunjukkan bahwa satu set yang berfungsi dengan baik pengaturan, yang kurang dalam setup kelembagaan di Nigeria mungkin diperlukan untuk membangun kapasitas kelembagaan yang diperlukan cocok untuk pengembangan sistem pembayaran elektronik yang aman dan efisien

6. "E-Payment System", Oleh Deni Trihasta, Julia Fajaryanti dari Journal Proceeding, Seminar Ilmiah Nasional Komputer dan Sistem Intelijen (Deni Trihasta, Julia Fajaryanti (2008) menerangkan Pembayaran secara "online" merupakan pembayaran barang dan servis melalui internet yang biasanya menggunakan kartu kredit. Transaksi keuangannya diproses secara elektronik dalam "real time". Proses pembayaran secara "online" telah marak dalam beberapa abad ini, dan dapat menjadi tugas yang berat dalam hal bisnis untuk mengimplementasikannya. Disini juga menjelaskan membandingkan tiap-tiap jenis dari e-payment tersebut,baik dari segi proses transaksi tiap-tiap jenis e-payment. Juga dibuat desain dari masing-masing e-payment dan cara pengimplementasiannya. Kita juga menampilkan bagaimana perkembangan pengguna e-payment di Indonesia. Pengguna e-payment di Indonesia sekarang ini cukup berkembang, banyak pengguna kartu kredit di indonesia yang lebih memilh menggunakan e-payment proses dalam melakukan setiap transaksi, baik transaksi pembelian barang ataupun servis.

\section{Pemecahan Masalah}

Sebagai institusi pendidikan di bidang ilmu komputer, salah satu aspek yang mendukung pelayanan mahasiswa adalah meningkatkan sistem pelayanan yang terintegrasi serta berbasis elektronik yang mampu memberikan informasi pembayaran dengan cepat yang diolah menjadi suatu informasi yang akurat didalam mengambil suatu keputusan didalam meningkatkan menyelesaikan suatu persoalan keuangan mahasiswa. Sistem pembayaran ini akan memanfaatkan teknologi informasi yang disebut sistem pembayaran online atau e-payment yang mana nantinya mahasiswa yang ingin menyelesaikan biaya perkuliahan cukup mentransfer melalui bank yang sudah ditunjuk oleh pihak penyelenggara pendidikan dan jika mahasiswa yang sudah membayar maka akan secara otomatis dapat langsung diverifikasi oleh bagian staff pelayanan di bagian keuangan pihak penyelenggara pendidikan. Sehingga hal ini akan mempermudah proses pengolahan data administrasi keuangan mahasiswa itu sendiri didalam menjalani proses pendidikan, dimana pada bagian administrasi keuangan ini 
akan menjadi tolak ukur didalam menentukan proses selanjutnya pada perkuliahan mahasiswa.

Dengan di buatnya aplikasi ini di harapkan mampu mendorong semua bagian didalam suatu lembaga pendidikan dalam meningkatkan kreatifitas pelayanan serta meningkatkan kualitas dan mutu pendidikan di Indonesia. Dengan adanya bantuan sistem informasi e-payment perusahaan mampu mengoptimalkan sumberdaya yang ada.Untuk mencapai tujuan tersebut, sistem informasi mempunyai peran yang penting bagi perusahaan untuk unggul dalam lingkungan bisnisnya. Beberapa fungsi dan manfaat sistem informasi dalam proses bisnis diantaranya adalah pemrosesan transaksi contoh terdekat yang sering kita lihat adalah pada minimarket atau supermarket. Bayangkan jika penjual melakukan transaksi secara manual, mereka harus mencatat satu persatu barang.Sekarang sudah ada software yang dapat membaca barcode pada produk tersebut.Contoh lainnya pada perbankan adalah internet banking. Bagi anda yang sibuk dengan aktivitas sehari-hari, anda dapat melakukan pembayaran telepon, air, penerbangan, dan lain sebagainya dimanapun anda berada. Kemudian pengawasan Dengan contoh yang sama pada swalayan, pemilik bisa mengawasi penjualan dari rumah tanpa harus mengunjungi swalaayan tersebut. Dengan menggunakan software pemilik dengan nyaman mengawasi barang masuk dan keluar dalam swalayan tersebut. Disamping itu terdapat penggalian informasi masih dengan contoh yang sama, software pada swalayan dapat diambil informasi mengenai jumlah penjualan dan sebagainya.

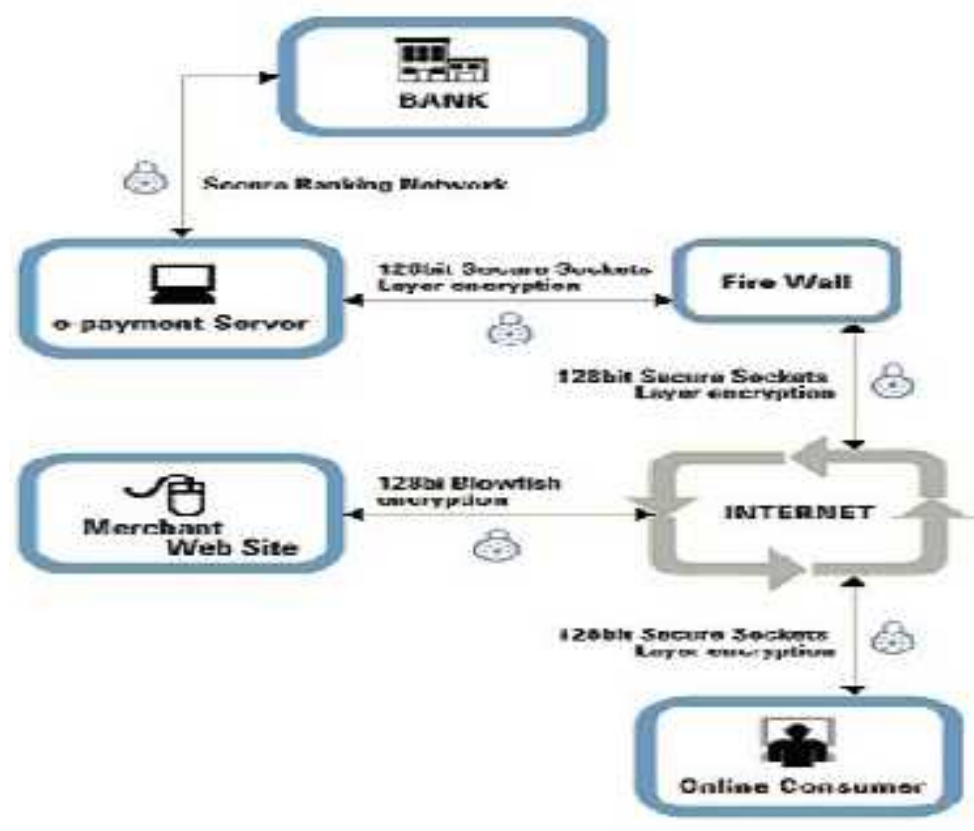

Gambar 2.6 Mekanisme Sistem E-Payment

Pengembangan Bussines Inteligence Sistem E-Payment Mahasiswa yang di Rancang oleh penulis adalah berbasis web, sistem dibangun untuk memudahkan user untuk melakukan pengolahan setiap transaksi pembayaran biaya kuliah dan juga pemvalidasian dan juga pelaporan di Universitas Banten Jaya. Untuk Proses pengolahan data transaksi pembayaran mahasiswa seorang petugas keuangan dapat dilakukan di komputer yang telah terhubung dengan jaringan internet. 


\section{Use Case Diagram}

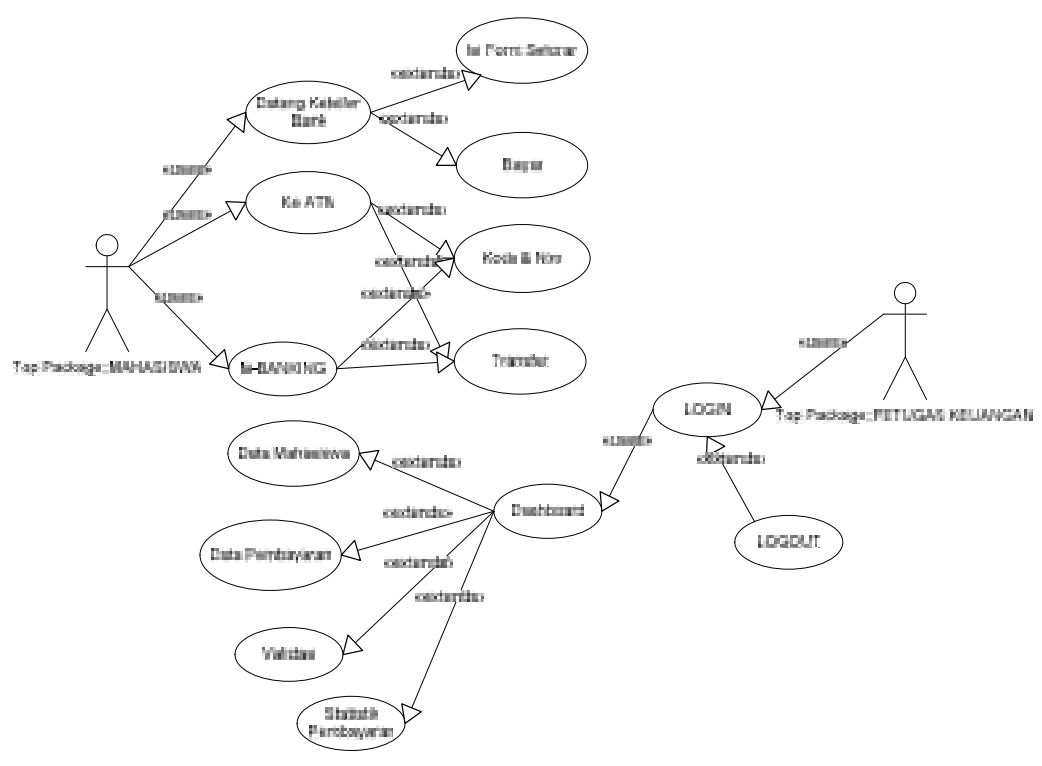

Gambar 7. Usecase Diagram Sistem E-Payment Univeritas Banten Jaya

Diagram diatas merupakan rancangan activity diagram yang menggambarkan aktifitas Use case sistem E-Payment di Universitas Banten Jaya secara umum dimana aktifitas tersebut dimulai dari mahasiswa melakukan proses pembayaran melalui Bak terdekat baik menggunakan ATM atau menggunakan aplikasi e-banking kemudia mahasiswa tersebut menyimpan kode pembayaran yang sudah diperoleh untuk diserahkan kepada pihak keuangan dan petugas keuangan meakukan validasi dengan cara membuka halaman pembayaran yang sudah disediakan pada dashboard sistem EPayment. Setelah halaman pembayaran tampil petugas keuangan memasukan nama mahasiswa dan secara otomatis akan tampil data mahasiswa berikut data pembayaran yang sudah dilakukan, untuk melakukan validasi petuagas keuangan cukup menginputkan kode validasi pada kolom yang sudah tersedia ketik apetugas berhasil membuka data pembayaran mahasiswa tersebut dengan menyesuaikan tanggal transaksi yang sudah dilakukan oleh mahasiswa ketika melakukan pembayaran

\section{IMPEMENTASI}

Hasil perancangan sistem diimplementasikan dengan menggunakan bahasa pemograman visual studio yang sangat familiar didunia pemrograman karena kemudahan dan juga fleksibilitasnya di berbagai sistem operasi.Didalam melakukan implementasi sistem memerlukan beberapa persyaratan agar sistem dapat berjalan dengan baik mulai dari dari persyaratan spesifikasi perangkat keras (hardware) yang harus digunakan hingga ke spesifikasi perangkat lunak (software).

Implementasi adalah suatu proses penerapan program yang telah dibuat kedalam sebuah aplikasi pemrograman sesuai dengan tujuan yang diharapkan dari program aplikasi tersebut. Kegiatan implementasi dilakukan dengan dasar yang telah direncanakan dalam tahap perancangan. Berikut ini adalah beberapa spesifikasi yang digunakan didalam melakukan implementasi diantaranya : 
a. Login Sistem

Login sistem adalah jendela yang pertama kali akan muncul ketika aplikasi dijalankan, merupakan bagian dari security sistem dimana aplikasi yang dapat digunakan oleh orang-orang tertentu yang sudah diberikan otoritas didalamnya dan dalam hal ini adalah bagian keuangan.

Pada bagian login terdapat 2 otoritas yang dapat masuk kedalam sistem diantaranya:

1. Administrator

Administrator memiliki akses penuh terhadap aplikasi sistem e-pyment dimana administrator memiliki hak untuk mengatur user yang dapat masuk serta menu yang lainnya.

2. User

User dalam hal ini pegawai dibagian keuangan hanya dapat melihat hasil transaksi dan juga hasil laporan pembayaran.

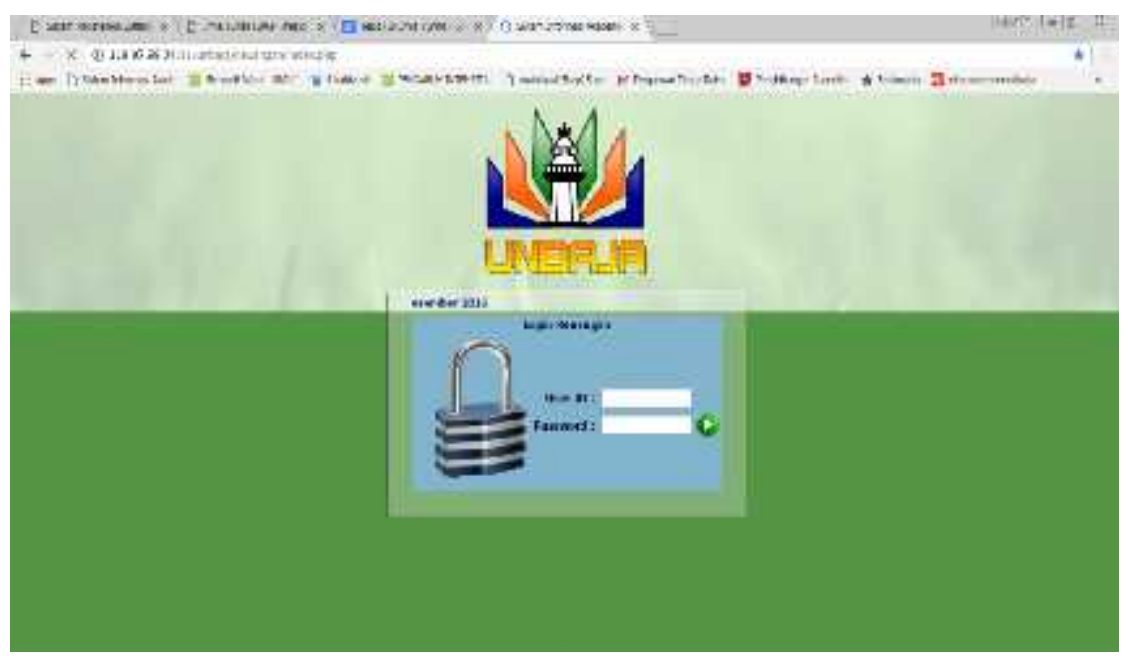

b. Menu Utama

Gambar 5.1 Login system

Menu utama administrator merupakan menu utama yang dapat diakses oleh administrator yang memiliki otoritas penuh.Menu ini terdiri dari enam halaman utama yang saling terhubung melalui tombol menu. 


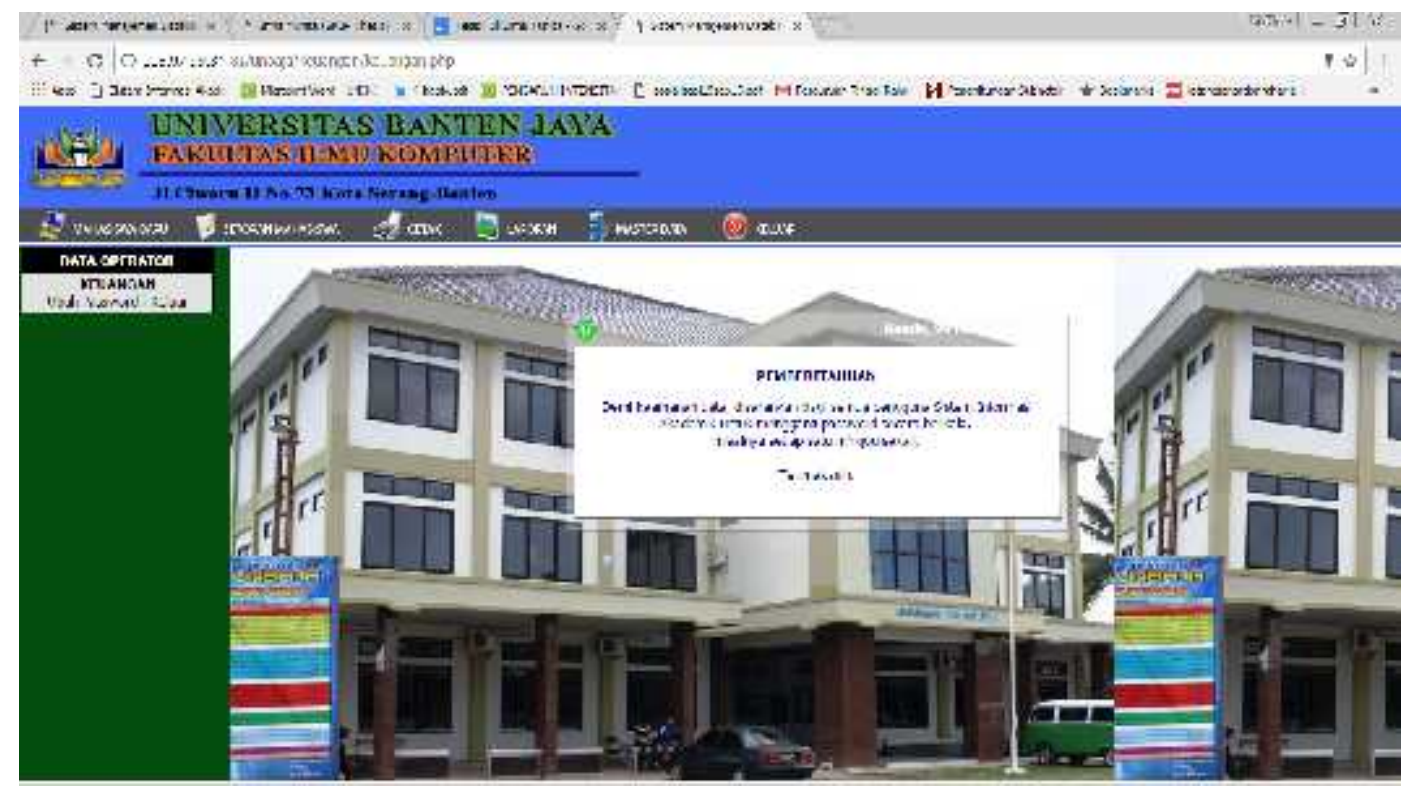

Gambar 5.2 Halaman Dashboard Utama

Terdapat 4 (empat) menu utama pada pada halaman menu administrator dan masing-masing menu terdapat beberapa sub menu sebagai berikut :

1. Menu Option

a. User

User adalah sub menu untuk memanggil halaman user yang berfungsi untuk mendaftarkan user baru atau merubah data user yang sudah ada.

b. Logout

Logout digunakan untuk mengakhiri aplikasi/program.

2. Menu Master

a. Mahasiswa Filkom

Digunakan untuk menyeleksi/melihat data mahasiswa aktif di fakultas ilmu komputer.

b. Mahasiswa FT

Digunakan untuk menyeleksi/melihat data mahasiswa aktif di fakultas teknik.

c. Mahasiswa FKIP

Digunakan untuk menyeleksi/melihat data mahasiswa aktif di fakultas keguruan dan ilmu pendidikan.

3. Keuangan Mahasiswa

a. Keuangan Faklutas Ilmu Komputer

Pada halaman ini terdapat beberapa fasilitas yang digunakan untuk menyeleksi transaksi pembayaran spp mahasiswa, bisa berdasarkan jurusan dan juga berdasarkan individu sehingga pihak keuangan dapat memantau setiap keuangan mahasiswa.

b. Keuangan Fakultas Teknik

Pada halaman ini terdapat beberapa fasilitas yang digunakan untuk menyeleksi transaksi pembayaran spp mahasiswa khusus dari fakultas teknik, bisa berdasarkan jurusan dan juga berdasarkan individu sehingga pihak keuangan dapat memantau setiap keuangan mahasiswa.

c. Keuangan Fakultas Fakultas Keguruan dan Ilmu Pendidikan 
Pada halaman ini terdapat beberapa fasilitas yang digunakan untuk menyeleksi transaksi pembayaran spp mahasiswa khusus dari fkip, bisa berdasarkan jurusan dan juga berdasarkan individu sehingga pihak keuangan dapat memantau setiap keuangan mahasiswa.

4. Laporan

a. Laporan keuangan mahasiswa

c. Halaman Utama System

1) Halaman User

Halaman Data Peserta berfungsi untuk menampilkan data user dan mengatur data user yang dapat otoritas untuk mengakses aplikasi e-payment.Pada halaman ini terdapat tombol Pendaftaran yang berfungsi untuk melakukan pendaftaran baru atau menyimpan data user baru.Selain itu, pada halaman ini juga dilengkapi tombol (Edit) dan (Hapus) yang berfungsi untuk melakukan edit dan hapus data peserta.

Proses pendaftaran dimulai dengan mengisi form pendaftaran dengan data peserta baru, selanjutnya klik tombol Simpan. Akan ditampilkan halaman konfirmasi data peserta untuk memastikan kesesuaian data peserta yang akan disimpan. Selanjutnya klik tombol Simpan untuk menyimpan data peserta ke dalam database.

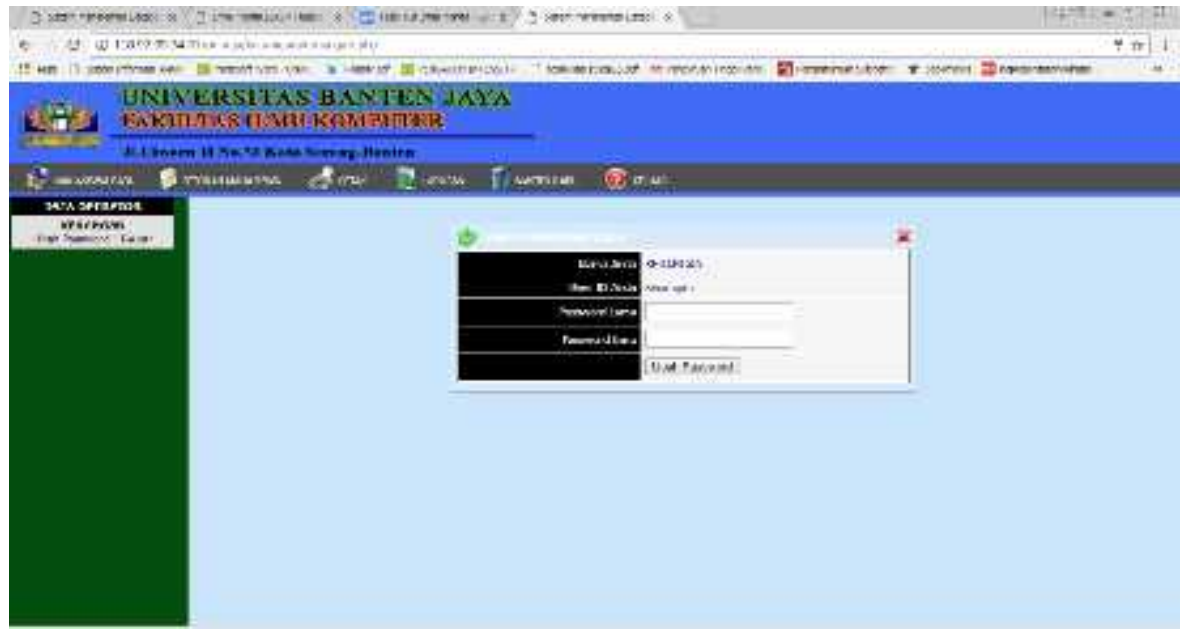

Gambar 5.3 Tampilan halaman user

Pada menu pengaturan pemakai terdapat button sebagai berikut :

5. Add : caranya diklik, digunakan untuk membuat/mendaftarkan user baru

6. Save : caranya diklik, digunakan untuk menyimpan data user baru

7. Exir : caranya diklik digunakan untuk mengakhiri pendaftaran user

2) Halaman Mahasiswa

Halaman Data mahasiswa berfungsi untuk menampilkan data mahasiswa dari seluruh fakultas dan bisa di seleksi berdasarkan jurusan. Halaman ini akan berguna bagi petugas keuangan untuk mengetahui data mahasiswa yang masih aktif ketika mencocokan dengan data keuangan mahasiswa. 


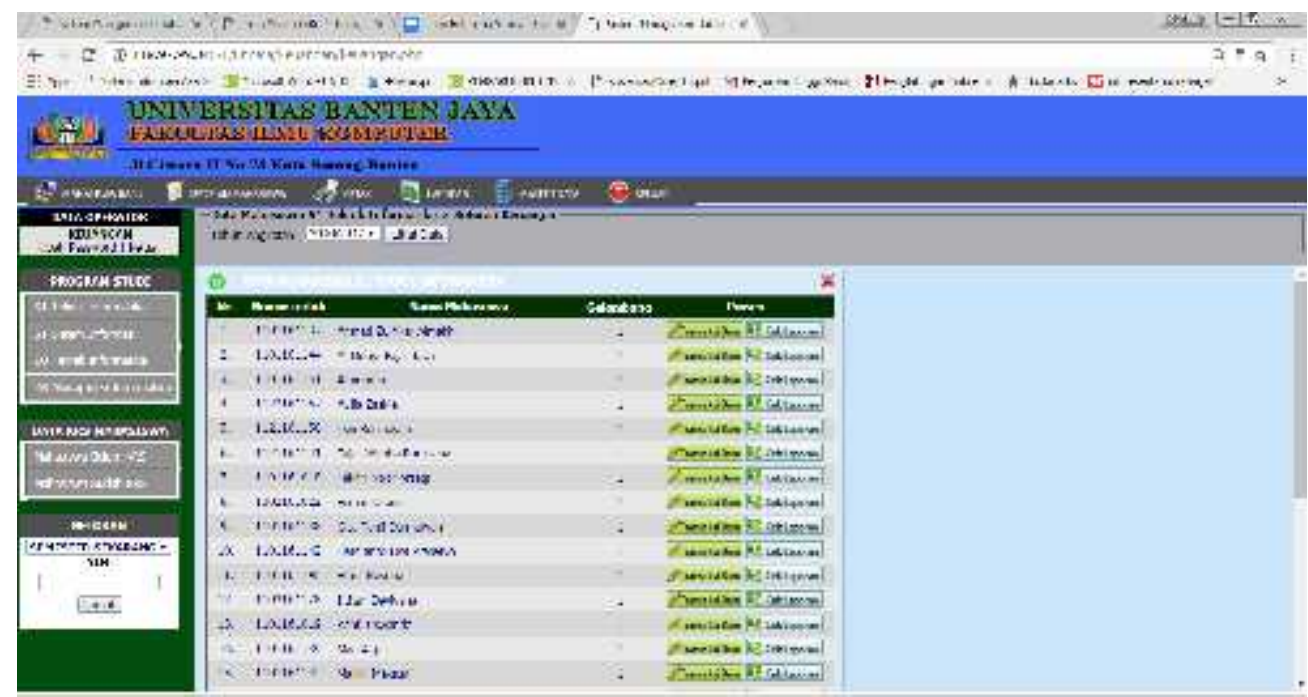

Gambar 5.4 Tampilan halaman mahasiswa

Pada menu halaman mahasiswa terdapat button sebagai berikut :

1. S1-TI : caranya diklik, digunakan untuk menampilkan daftar mahasiswa dari jurusan S1-TI (Teknik Informatika).

2. S1-SI : caranya diklik, digunakan untuk menampilkan daftar mahasiswa dari jurusan S1-SI (Sistem Informasi).

3. D3-TI : caranya diklik, digunakan untuk menampilkan daftar mahasiswa dari jurusan D3-TI (D3 Teknik Informatika).

4. D3-MI : caranya diklik, digunakan untuk menampilkan daftar mahasiswa dari jurusan D3-TI (D3 Manajemen Informatika).

d. Analisis Data dan Implikasi

Berdasarkan gambar 5.5 dapat diketahui bahwa mahasiswa serta pegawai yang terpilih sebagai responden sebanyak 53 orang dan tidak terbatas pada jenis kelamin tertentu. Data yang diperoleh melalui kuesioner yang diisi oleh responden menunjukan bahwa frekuensi responden laki-laki sebesar 45,3\%, sedangkan frekuensi responden perempuan sebesar $54,7 \%$. Jadi dapat disimpulkan bahwa mayoritas responden dalam penelitian ini adalah perempuan.

1. Tanggapan responden

Tanggapan responden terhadap instrumen penelitian Sistem Informasi Absensi adalah sebagai berikut :

Pernyataan : "Sistem E-Payment telah memberikan kemudahan bagi mahasiswa."

Tanggapan responden terhadap pernyataan ini disajikan dalam bentuk gambar yang sudah diproses melalui rinfo form sebagai berikut. 


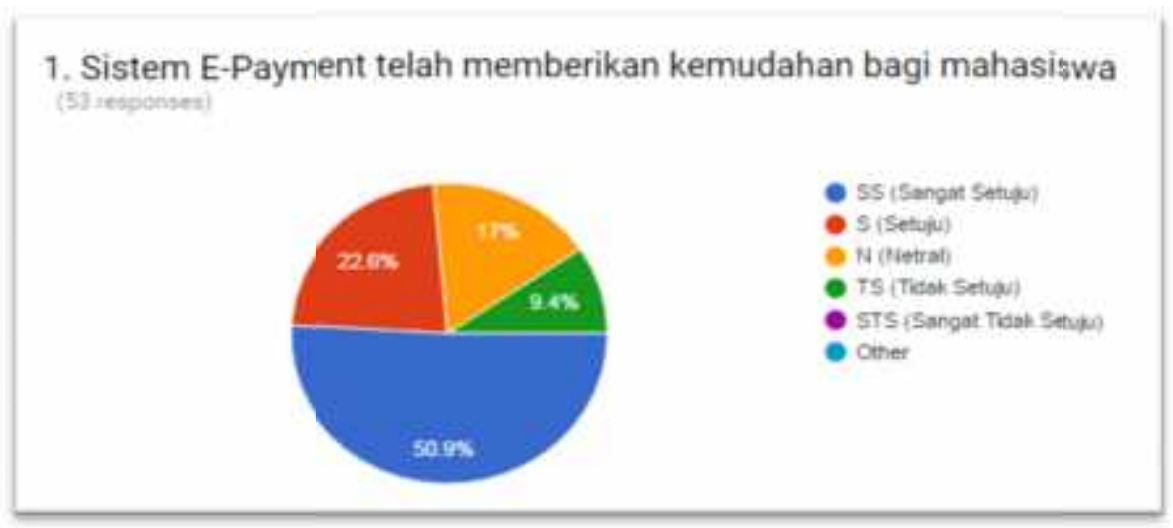

Gambar 5.6

Responden Berdasarkan Pernyataan 1

Berdasarkan tabel diatas dapat dilihat bahwa tanggapan responden terhadap pernyataan 1 sebesar $50,9 \%$ yang menjawab sangat setuju dan persentase sebesar $22,6 \%$ yang menjawab setuju sedangkan sebesar $17 \%$ yang menjawab netral dan $9,4 \%$ yang menjawab tidak setuju. maka dapat disimpulkan bahwa hampir seluruh responden merasa bahwa sistem e-payment telah memberikan kemudahan bagi mahasiswa.

1. Pernyataan : "Informasi yang diperloeh dari sistem e-payment telah sesuai dengan yang diharapkan."

Tanggapan responden terhadap pernyataan ini disajikan dalam bentuk gambar yang sudah diproses melalui rinfo form sebagai berikut.

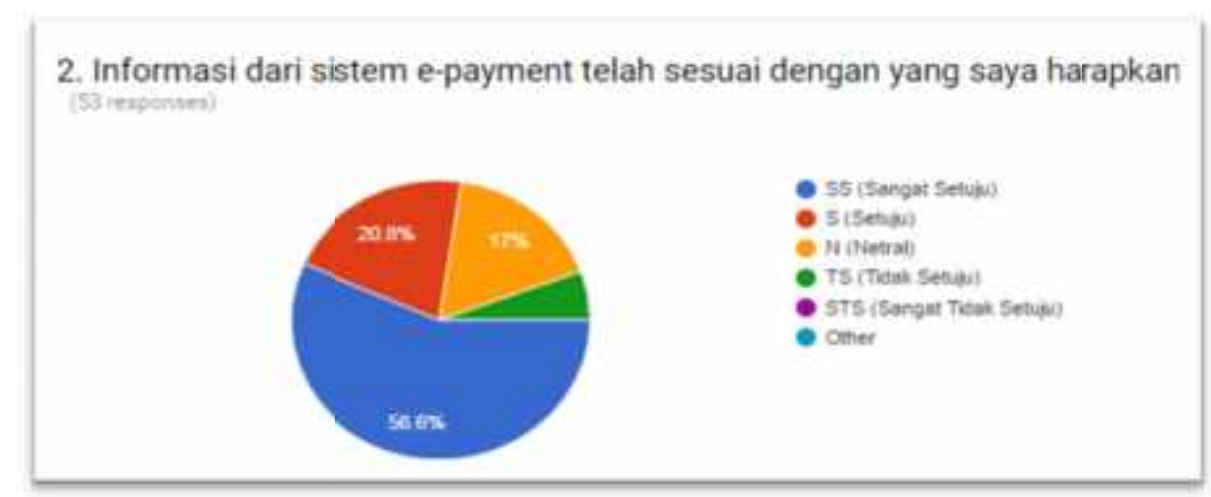

Gambar 5.7

Responden Berdasarkan Pernyataan 2

Berdasarkan tabel diatas dapat dilihat bahwa tanggapan responden terhadap pernyataan 1 sebesar 56,6\% yang menjawab sangat setuju dan persentase sebesar 20,6\% yang menjawab setuju sedangkan sebesar $17 \%$ yang menjawab netral. maka dapat disimpulkan bahwa hampir seluruh responden merasa bahwa sistem e-payment telah memberikan informasi yang dihasilkan sesuai dengan harapan bagian keuangan. 
2. Pernyataan : "Sistem E-Payment lebih baik dari sistem pembayaran SPP sebelumnya."

Tanggapan responden terhadap pernyataan ini disajikan dalam bentuk gambar yang sudah diproses melalui rinfo form sebagai berikut.

\section{Sistem E-Payment lebih baik dari sistem pembayaran SPP sebelumnya}

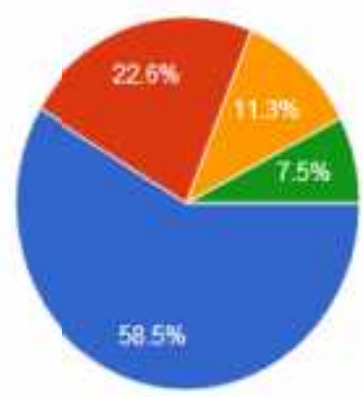

- ss (Sangat Setulu)

Q 8 (Setuju)

- N (Netral)

- TS (Tidak Setuju)

- STS (Sangat Tidak Setuju)

Other

Gambar 5.8

Responden Berdasarkan Pernyataan 3

Berdasarkan tabel diatas dapat dilihat bahwa tanggapan responden terhadap pernyataan 3 sebesar $58,5 \%$ yang menjawab sangat setuju dan persentase sebesar 22,6\% yang menjawab setuju sedangkan sebesar 11,3\% yang menjawab netral dan 7,5\% yang menjawab tidak setuju. maka dapat disimpulkan bahwa hampir seluruh responden merasa bahwa dengan adanya sistem epayment lebih baik dan telah memberikan kemudahan bagi mahasiswa.

3. Pernyataan : "Sistem E-Payment membuat data keuangan SPP mahasiswa menjadi tidak aman."

Tanggapan responden terhadap pernyataan ini disajikan dalam bentuk gambar yang sudah diproses melalui rinfo form sebagai berikut. 


\section{Sistem e-payment membuat data keuangan spp mahasiswa menjadi tidak} aman

(59) reaponses:
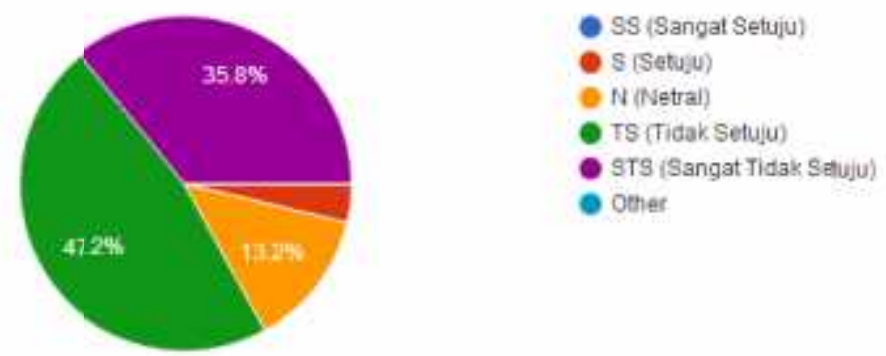

Gambar 5.8 Responden Berdasarkan Pernyataan 4

Berdasarkan tabel diatas dapat dilihat bahwa tanggapan responden terhadap pernyataan 4 sebesar $13,2 \%$ yang menjawab netral, 35,8\% yang menjawab sangat tidak setuju dan $47,2 \%$ yang menjawab tidak setuju. maka dapat disimpulkan bahwa hampir seluruh responden merasa bahwa sistem epayment ini dapat membuat data keuangan dalam hal ini adalah SPP mahasiswa menjadi aman.

4. Pernyataan : "Sistem E-Payment membantu saya untuk melakukan pembayaran biaya pendidikan di perguruan tinggi."

Tanggapan responden terhadap pernyataan ini disajikan dalam bentuk gambar yang sudah diproses melalui rinfo form sebagai berikut.

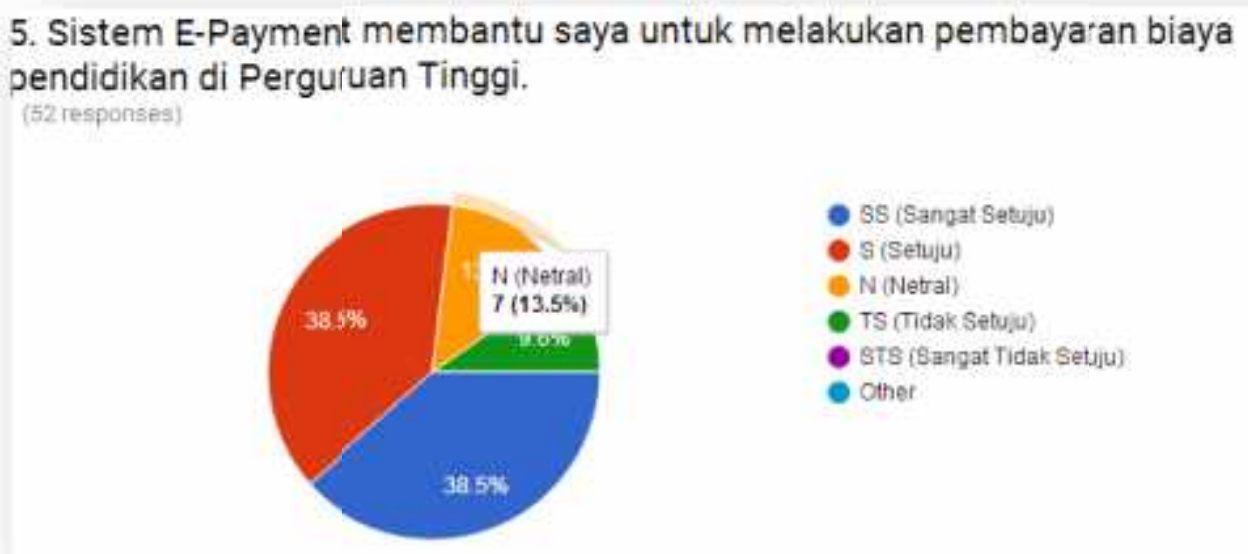

Gambar 5.9

Responden Berdasarkan Pernyataan 5

Berdasarkan tabel diatas dapat dilihat bahwa tanggapan responden terhadap pernyataan 5 sebesar $38,5 \%$ yang menjawab sangat setuju dan persentase sebesar $38,5 \%$ yang menjawab setuju sedangkan sebesar $13,5 \%$ yang 
menjawab netral dan 9,6\% yang menjawab tidak setuju. maka dapat disimpulkan bahwa hampir seluruh responden merasa bahwa sistem e-payment dapat membantu mahasiswa dalam melakukan pembayaran di suatu perguruan tinggi.

5. Pernyataan : "Sistem E-Payment memberikan informasi keuangan mahasiswa lebih cepat dan akurat."

Tanggapan responden terhadap pernyataan ini disajikan dalam bentuk gambar yang sudah diproses melalui rinfo form sebagai berikut.

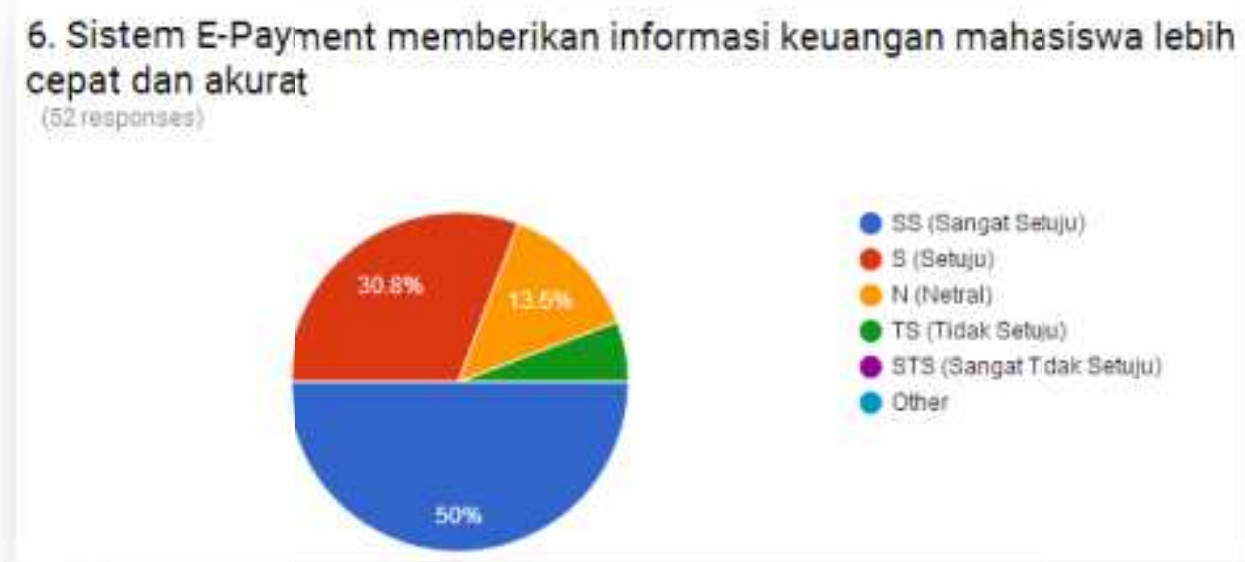

Gambar 5.10

Responden Berdasarkan Pernyataan 6

Berdasarkan tabel diatas dapat dilihat bahwa tanggapan responden terhadap pernyataan 6 sebesar 50\% yang menjawab sangat setuju dan persentase sebesar $30,8 \%$ yang menjawab setuju sedangkan sebesar $13,5 \%$ yang menjawab netral. maka dapat disimpulkan bahwa hampir seluruh responden merasa bahwa sistem e-payment dapat memberikan informasi keuangan mahasiswa lebih cepat dan akurat.

6. Pernyataan : "Sistem E-Payment membuat proses pembayaran menjadi lebih sulit."

Tanggapan responden terhadap pernyataan ini disajikan dalam bentuk gambar yang sudah diproses melalui rinfo form sebagai berikut. 


\section{Sistem E-Payment membuat proses pembayaran menjadi lebih sulit}

\section{(5) respondes}

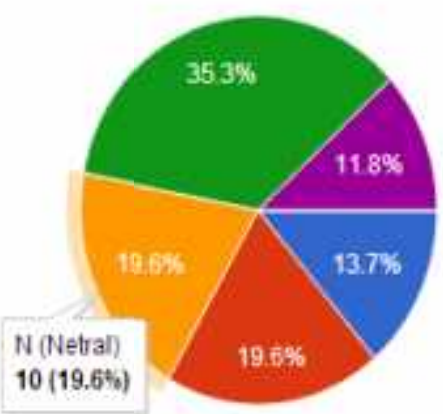

SS (Sangat Setuju)

S (Setuju)

N(Netral)

TS (Tidak Setuju)

sTS (Sangat Tidak Setuju)

other

Gambar 5.11

Responden Berdasarkan Pernyataan 7

Berdasarkan tabel diatas dapat dilihat bahwa tanggapan responden terhadap pernyataan 7 sebesar $13,7 \%$ yang menjawab sangat setuju dan persentase sebesar 19,6\% yang menjawab setuju sedangkan sebesar 19,6\% yang menjawab netral, $11,8 \%$ yang menjawab sangat tidak setuju dan $35,3 \%$ yang menjawab tidak setuju. maka dapat disimpulkan bahwa rata-rata responden merasa bahwa sistem e-payment dapat membantu proses pembayaran menjadi lebih mudah.

7. Pernyataan : "Sistem E-Payment dapat meningkatkan pengetahuan saya tentang system pembayaran elektronis"

Tanggapan responden terhadap pernyataan ini disajikan dalam bentuk gambar yang sudah diproses melalui rinfo form sebagai berikut.

\section{Sistem E-Payment dapat meningkatkan pengetahuan saya tentang sistem pembayaran elektronis}

(5T responses)
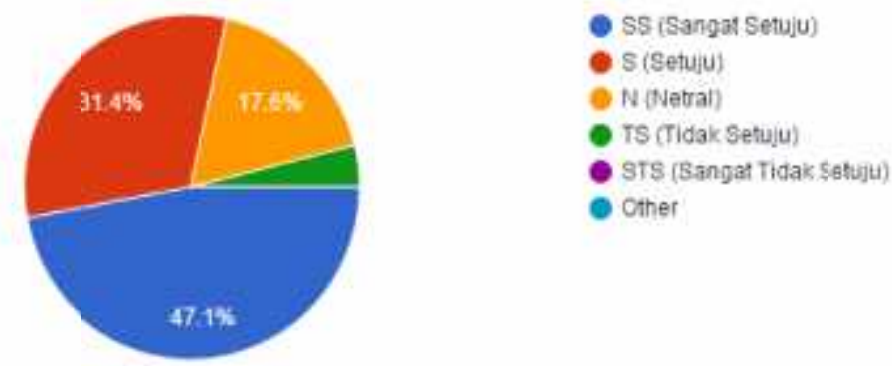

Gambar 5.12

Responden Berdasarkan Pernyataan 8 
Berdasarkan tabel diatas dapat dilihat bahwa tanggapan responden terhadap pernyataan 8 sebesar $47,1 \%$ yang menjawab sangat setuju dan persentase sebesar 31,4\% yang menjawab setuju sedangkan sebesar 17,6\% yang menjawab netral. maka dapat disimpulkan bahwa hampir seluruh responden merasa bahwa sistem e-payment dapat meningkatkan pengetahuan tentang system pembayaran elektronis.

8. Pernyataan : "Sistem E-Payment mampu meningkatkan produktivitas saya dalam melakukan pembayaran SPP online."

Tanggapan responden terhadap pernyataan ini disajikan dalam bentuk gambar yang sudah diproses melalui rinfo form sebagai berikut.

\section{Sistem E-Payment mampu meningkatkan produktivitas saya dalam melakukan pembayaran SPP online. \\ (52 responses)}

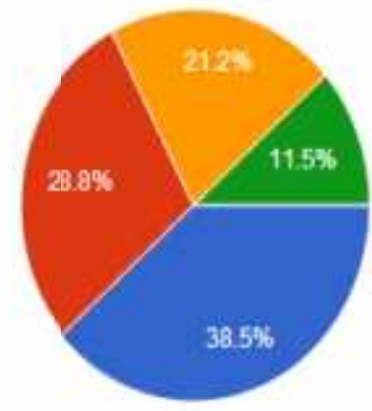

Gambar 5.13

Responden Berdasarkan Pernyataan 9

Berdasarkan tabel diatas dapat dilihat bahwa tanggapan responden terhadap pernyataan 9 sebesar $38,5 \%$ yang menjawab sangat setuju dan persentase sebesar $28,8 \%$ yang menjawab setuju sedangkan sebesar $21,2 \%$ yang menjawab netral dan $11,5 \%$ yang menjawab tidak setuju. maka dapat disimpulkan bahwa hampir seluruh responden merasa bahwa sistem e-payment dapat meningkatkan produktivitas dalam melakukan pembayaran SPP online.

9. Pernyataan : "Sistem E-Payment lebih banyak manfaat yang saya dapatkan dibandingkan dengan kerugiannya"

Tanggapan responden terhadap pernyataan ini disajikan dalam bentuk gambar yang sudah diproses melalui rinfo form sebagai berikut. 


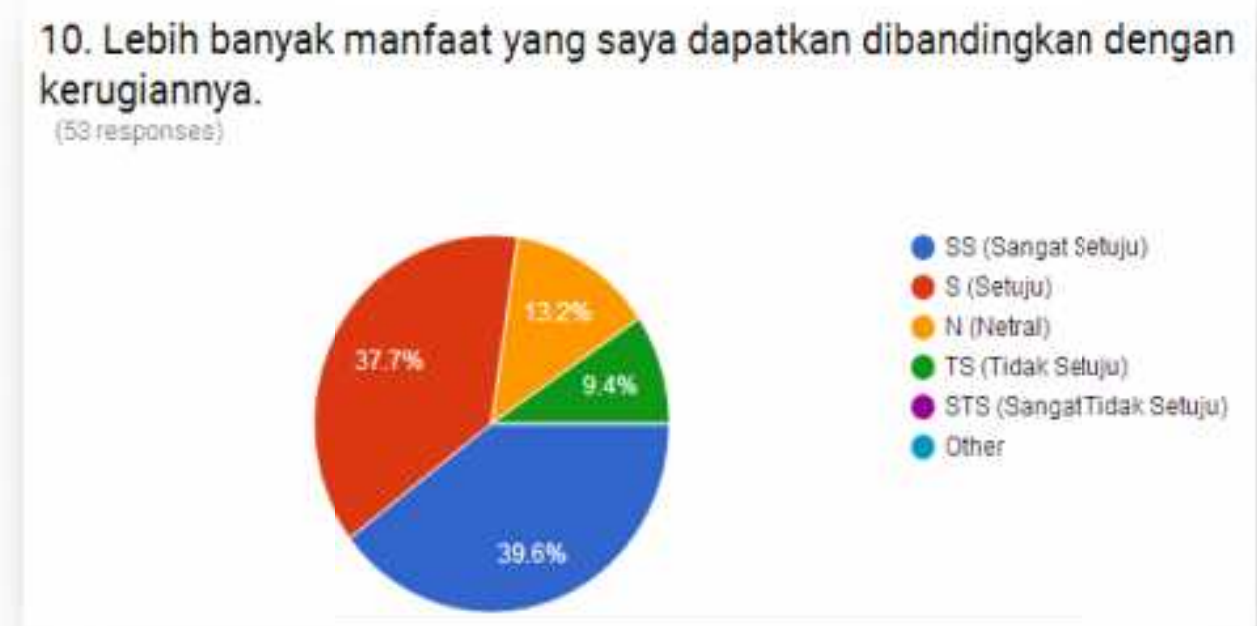

Gambar 5.14

Responden Berdasarkan Pernyataan 10

Berdasarkan tabel diatas dapat dilihat bahwa tanggapan responden terhadap pernyataan 10 sebesar 39,6\% yang menjawab sangat setuju dan persentase sebesar $37,7 \%$ yang menjawab setuju sedangkan sebesar $13,2 \%$ yang menjawab netral dan 9,4\% yang menjawab tidak setuju. maka dapat disimpulkan bahwa hampir seluruh responden merasa bahwa sistem e-payment lebih banyak manfaatnya dibandingkan kerugiannya.

Berikut adalah penjelasan data rekapitulasi hasil kuesioner untuk implementasi sistem e-payment terhadap variabel manfaat yang dapat dirasakan oleh mahasiswa dan juga staff keuangan.

Berdasarkan data pada hasil kuisioner, maka dapat dijelaskan jumlah responden sebanyak 53 orang dan bisa dianalisa sebagai berikut:

Skor ideal $=5600$.

Skor aktual $=5465$.

Jadi bisa didapatkan presentasenya adalah

$$
\begin{aligned}
& \% \text { Skor aktual }=\frac{\text { Skor aktual }}{\text { Skor ideal }} \times 100 \% \\
& \% \text { Skor aktual }=\frac{5046}{5600} \times 100 \%
\end{aligned}
$$

Maka hasilnya sebesar 90,11\%, skor ini berada dalam kriteria sangat baik. Implikasinya adalah dengan adanya implementasi sistem e-payment, data yang dibutuhkan untuk keperluan penilaian yang berkualitas dapat menjadi mudah didapatkan dan diolah menjadi informasi sesuai dengan kebutuhan pengguna yang telah disajikan dalam Sistem Kuliah Portofolio (SkuP).

\section{KESIMPULAN}

Dengan demikian, dapat disimpulkan bahwa implementasi sistem e-payment pada Universitas Banten Jaya adalah suatu sistem informasi yang berada dalam 
perangkat lunak berbasis online yang digunakan untuk membantu mahasiswa didalam melakukan pembayaran dan juga bagian pelayanan dibagian keuangan serta membantu manajemen didalam memperoleh informasi seakurat mungkin dan secepat meungkin.

Dari uraian pembahasan pada bab sebelumnya maka kesimpulan dari penelitian ini adalah sebagai berikut:

1. Dengan adanya sistem e-payment di Universitas Banten Jaya dapat membantu pelayanan administrasi keuangan menjadi lebih mudah dan selaras dengan tujuan universitas yang menyelenggarakan program studi ilmu komputer untuk dapat membangun sistem pelayanan pembayaran mahasiswa yang terkomputerisasi.

2. Dengan adanya sistem e-payment dapat membantu mengolah data pembayaran mahasiswa menjadi lebih cepat dan lebih efektif meskipun jumlah mahasiswa terus meningkat.

3. Dengan adanya sistem e-payment dapat memberikan informasi yang cepat dan akurat terkait masalah keuangan mahasiswa sehingga dapat membantu pihak keuangan didalam membuat suatu keputusan.

4. Sistem e-payment di Universitas Banten Jaya telah sesuai dengan tujuan universitas, hal ini telah dibuktikan dengan hasil kuesioner yang disebar kepada lebih dari 50 responden lebih dari 68,2\% menyatakan sangat setuju.

\section{SARAN}

Diharapakan kedepannya perlu ada adanya pengembangan dashboard yang dapat menghasilkan laporan keuangan secara cepat dalam bentuk statistic kepada setiap mahasiswa dan juga manajemen untuk memperoleh informasi dengan mudah bahan untuk pengambilan keputusan .

\section{DAFTAR PUSTAKA}

[1] Adiyanti, Arsita Ika. 2015. Pengaruh Pendapatan, Manfaat, Kemudahan Penggunaan, Daya Tarik Promosi, dan Kepercayaan terhadap Minat menggunakan layanan E-money. Jurnal Ilmu Ekonomi Univeristas Brawijaya.

[2] Anshori, Mochammad Hafiz, 2014. "Pengembangan Sistem Pembayaran Elektronik Menggunakan Kode Qr Berbasis Android". Jurnal POMITS. 2Edhy Sutanta, S.T. 2003. Sistem Informasi Manajemen. Graha ilmu.

[3] Azhar Susanto. 2013. Sistem Informasi Akuntansi. Bandung: Lingga Jaya.

[4] Azhar Susanto. 2004. "Sistem Informasi Manajemen. Konsep dan Pengembangannya”. Lingga Jaya, Bandung.

[5] Austin Briggs, Laurence Brooks, 2011, "Electronic Payment Systems Development In A Developing Country: The Role Of Institutional Arrangements" The Electronic Journal on Information Systems in Developing Countries ejisdc.org.vol 3. 2009. 
[6] Babin, Barry J : Lee, Yong-Kie, Eun-Fu: dan Griffin, Mitch (2005). Journal of Service Marketing Vol. 19, Modeling Comsumer Satisfaction and Word of Mounth : Restaurant Patronage Korea, Journal of Service Marketing.

[7] Candrawati, Ni Nyoman Anita. 2013. "Perlindungan Hukum terhadap Pemegang Kartu E-money sebagai Alat Pebayaran dalam Transaksi Komersial”. Jurnal Ekonomi Universitas Udayana.

[8] Chan, Kah Sing.2004. Electronic Commerce and Supply Chain Management. 2nd edition. Thomas Learning Asia,Singapore.

[9] Erikson Damanik, 2012. "Perancangan Sistem Informasi Pembayaran Online Menggunakan Payment Gateway". JSM STMIK Mikroskil. 13.

[10] Ghifary, Muhammad. 2010. Rancangan Protokol Modifikasi Transaksi Belanja Online dengan Kartu Kredit Secara CNP (Card Not Present).

[11] Hanif Al Fatta. 2007. Analisis \& Perancangan Sistem Informasi, untuk Keunggulan Bersaing Perusahaan \& Organisasi Modern. Andi, Yogyakarta.

[12] Husaini Usman dan Purnomo, 2008. Metodologi Penelitian Sosial. Penerbit PT Bumi Aksara : Jakarta.

[13] Jiawei, Han., Micheline, Kamber, 2006. Data Mining: Concepts and Techniques. Amsterdam: Morgan Kaufmann Publishers

[14] Jogiyanto, 2010. Analisis dan Desain Sistem Informasi, Edisi IV, Andi Offset, Yogyakarta.Raymond McLeod, 2004. Sistem Informasi Manajemen, PT. Indeks. Jakarta.

[15] Imam Ghozali dan Murdik al Mansur, 2002, Analisis Faktor-Faktor Yang Mempengaruhi Tingkat Underpricing di Bursa Efek Indonesia.Jurnal Bisnis dan Akuntansi, vol.4, No.1,April.

[16] Karamjeet Kaur , Dr. Ashutosh Pathak. 2015. "E-Payment System on ECommerce in India”. Journal of Engineering Research and Applications ijeera.com.5.

[17] Nur Hidayati. (2006). Analisis Faktor - Faktor Yang Mempengaruhi Dividen Kas Di Bursa Efek Jakarta. Jogjakarta : Fakultas Ekonomi Universitas Islam Indonesia

[18] O’Brien, James A.; Marakas, George M, 2008. Management Information Systems. 8th Edition. New York, McGraw Hill.

[19] Saiful Bahri, Asep. 2010. “Konsep Uang Elektronik dan Peluang Implemetasinya Pada Perbankan Syariah (Studi Kritis Terhadap Peraturan Bank Indonesia No. 11/12/PBI/2009 Tentang Uang Elektronik)." Laporan Hasil Penelitian Skripsi UIN Syarif Hidayatullah, Jakarta.

[20] Suparto Darudiato, Sigit Wisnu Santoso, Setiady Wiguna "Business Intelligence: Konsep Dan Metode”Jakarta.

[21] Tri Suci Gandawati. 2013. "Analisis Proses Adopsi Electronic Payment System Dengan Menggunakan Utaut Model”. Jurnal Universitas Narotama Surabaya. 